\title{
The origin of a zoned ignimbrite: insights into the Campanian Ignimbrite magma chamber (Campi Flegrei, Italy)
}

Francesca Forni ${ }^{1 *}$, Olivier Bachmann ${ }^{1}$, Silvio Mollo ${ }^{2,3}$, Gianfilippo De Astis ${ }^{3}$, Sarah E. Gelman $^{4}$, Ben S. Ellis ${ }^{1}$

${ }^{1}$ Institute of Geochemistry and Petrology, ETH Zürich, Clausiusstrasse 25, 8092 Zürich, Switzerland

${ }^{2}$ Dipartimento di Scienze della Terra, Sapienza-Università di Roma, P.le Aldo Moro 5, 00185 Roma, Italy

${ }^{3}$ Istituto Nazionale di Geofisica e Vulcanologia, via di Vigna Murata 605, 00143, Roma, Italy ${ }^{4}$ ExxonMobil Upstream Research Company, Spring, TX 77389, USA.

* corresponding author; e-mail: francesca.forni@erdw.ethz.ch; office phone: +41 0446327989

\begin{abstract}
Caldera-forming eruptions, during which large volumes of magma are explosively evacuated into the atmosphere from shallow crustal reservoirs, represent one of the most hazardous natural events on Earth. The Campanian Ignimbrite (CI; Campi Flegrei, Italy) represents a classical example of such events, producing a voluminous pyroclastic sequence of trachytic to phonolitic magma that covered several thousands of squared kilometers in the south-central Italy around $39 \mathrm{ka}$ ago. The CI deposits are known for their remarkable geochemical gradients, attributed to eruption from a vertically zoned magma chamber. We investigate the relationships between such chemical zoning and the crystallinity variations observed within the CI pyroclastic sequence by combining bulk-rock data with detailed analyses of crystals and matrix glass from well-characterized stratigraphic units. Using geothermometers and hygrometers specifically calibrated for alkaline magmas, we reconstruct the reservoir storage
\end{abstract}


conditions, revealing the presence of gradients in temperature and magma water content. In particular, we observe a decrease in crystallinity and temperature and an increase in magma evolution and water content from the bottom to the top of the magma chamber. We interpret these features as the result of protracted fractional crystallization leading to the formation of a cumulate crystal mush at the base of the eruptible reservoir, from which highly evolved, crystal-poor, water-rich and relatively cold melts were separated. The extracted melts, forming a buoyant, easily eruptible cap at the top of the magma chamber, fed the initial phases of the eruption, until caldera collapse and eruption of the deeper more crystalline part of the system. This late-erupted, crystal-rich material represents remobilized portions of the cumulate crystal mush, partly melted following hotter recharge. Our interpretation is supported by: 1) the positive bulk-rock Eu anomalies and the high $\mathrm{Ba}$ and $\mathrm{Sr}$ contents observed in the crystal-rich units, implying feldspar accumulation; 2) the positive Eu anomalies in the matrix glass of the crystal-rich units, testifying to the presence of liquid derived from partial melting of low temperature mineral phases within the crystal mush (mostly feldspars); 3) the $\mathrm{Ba}$ and Sr-rich rims in the feldspars and positive Eu anomalies in clinopyroxene rims, suggesting late rim growth from a locally enriched melt following cumulate mush remelting and 4) the occurrence of An-rich plagioclase, relict from a more mafic recharge, which acted as a heat source. Our model reconciles many observations made over the years on zoned deposits of such high-magnitude explosive eruptions, and provides a framework to understand magma chamber processes leading up to such cataclysmic events.

Keywords: Zoned ignimbrites, Phonolites, Cumulates, Campi Flegrei, Campanian Ignimbrite

\section{Introduction}

Understanding the mechanisms that lead to the generation of large upper crustal reservoirs resulting in large explosive eruptions is one of the most challenging tasks for modern volcanology. Zoned ignimbrites, which record significant compositional and thermal gradients in such shallow magma reservoirs, represent an exceptional archive of information 
on magma storage conditions and evolutionary processes (Civetta et al., 1997; Hildreth, 1981; Lipman, 1971; Smith and Bailey, 1966; Wark et al., 2007). The origin of chemical and thermal zoning has been debated for years, with hypotheses ranging from magma mixing (e.g. Dorais et al., 1991; Hervig and Dunbar, 1992; Troll and Schmincke, 2002) to in-situ differentiation driven by crystal-liquid separation (e.g. Bacon and Druitt, 1988; de Silva, 1991; Hildreth, 2004). Although mixing of different magma batches remains popular as the cause of geochemical and isotopic heterogeneities in magma reservoirs (see also Bindeman and Valley, 2003; Sumner and Wolff, 2003), the importance of in-situ differentiation processes in generating and maintaining chemical and physical gradients, has been recently reiterated (Bachmann and Bergantz, 2008; Medlin et al., 2015; Sliwinski et al., 2015). In a fractional crystallization-dominated scenario, crystal-liquid separation occurs most efficiently at an intermediate crystallinity stage ( $\sim 50-70 \%$ crystals), when convection in the magma chamber has ceased (Bachmann and Bergantz, 2004). In this crystallinity window, conditions are suitable for hindered settling, microsettling and/or high permeability compaction to extract crystal-poor and highly evolved melts from the relatively high permeability crystal mush zones, generating a buoyant and easily eruptible cap in the upper part of the magma chamber (Dufek and Bachmann, 2010; Hildreth, 2004). Crystal cumulates can be remobilized by partial melting processes, which lower their crystallinity and increase their buoyancy, when heat and volatiles are transferred from mafic recharges (Huber et al., 2012; Parmigiani et al., 2014; Pistone et al., 2013). In this framework, it is the combination of in-situ differentiation and interaction with hotter recharges that is responsible for the generation of gradients in zoned ignimbrites (Deering et al., 2011; Pamukcu et al., 2013; Wolff et al., 2015).

In this paper, we focus on the Campanian Ignimbrite (CI), erupted at Campi Flegrei (southern Italy) during the largest volcanic event in the Mediterranean area over the past $200 \mathrm{ka}$. The CI is well-known for its remarkable bulk-rock geochemical variations that are observed from the bottom to the top of the pyroclastic sequence and have been attributed to eruption from a vertically zoned magma chamber (Arienzo et al., 2009; Civetta et al., 1997; Pappalardo et al., 
2008; Signorelli et al., 1999). Despite the presence of a wide literature on the CI, the relationship between the chemical zoning and the processes that led to the growth of such a large magma reservoir in the upper crust remains controversial. In order to fill this gap, we combine new and literature data on bulk-rock major and trace elements from juvenile clasts with a detailed micro-analytical study of phenocrysts and coexisting glasses from well characterized stratigraphic units. Moreover, we use geothermometers, hygrometers and oxygen barometers specifically calibrated for alkaline magmas to estimate the pre-eruptive storage conditions and apply geochemical models to account for the behaviour of key trace elements in the CI system.

\section{Volcanological background}

\subsection{Campi Flegrei}

The Campi Flegrei caldera is an active volcano located in the Campanian Plain (southern Italy; Fig. 1), a highly populated area affected by extensional tectonics since the Pliocene due to the opening of the back-arc Tyrrhenian basin behind the Apennine subduction zone (e.g. Scandone and Patacca, 1984). The time of onset of volcanism at Campi Flegrei is unknown; the oldest subaerial erupted products yield ages of about $60 \mathrm{ka}$ and are related to volcanism extending beyond the limits of the present caldera (Pappalardo et al., 1999). However, geochronological investigations of drillcores from the Campanian Plain extend the age of the magmatic activity to over 200 ka (De Vivo et al., 2001). The present nested and resurgent caldera structure formed as a consequence of two cataclysmic explosive eruptions, the CI

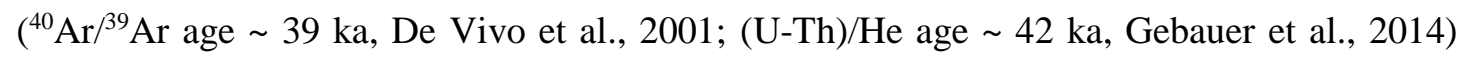
and the Neapolitan Yellow Tuff (14.9 ka, Deino et al., 2004), during which $\sim 200$ and $\sim 40$ $\mathrm{km}^{3} \mathrm{DRE}$ (dense rock equivalent) of magma were respectively erupted (Civetta et al., 1997; Orsi et al., 1992). Within the last $~ 15 \mathrm{ky}$, the Campi Flegrei caldera was the site of intense volcanic activity with more than 70 phreatomagmatic eruptions (Di Vito et al., 1999), the most recent of which built up the Monte Nuovo cone (A.D. 1538; Di Vito et al., 1987). 
Diffuse fumarolic and seismic activity and recurrent episodes of unrest have been also documented in the past 45 years (Orsi et al., 1999). The composition of magmas erupted within the Campi Flegrei caldera varies from shoshonite to phonolite, with trachyte and phonolite the most abundant (D'Antonio, 2011 and references therein). Following the two caldera-forming events (CI and Neapolitan Yellow Tuff), less evolved magmas (shoshonite and latite) were sporadically erupted close to the caldera rims (Di Vito et al., 1999).

\subsection{Campanian Ignimbrite}

The CI is a voluminous and widespread pyroclastic sequence composed of a basal fallout deposit and distinct pyroclastic flow units (Civetta et al., 1997) (Fig. 1). In the last decades, several studies about the CI have reported different stratigraphic reconstructions obtained using both proximal and distal deposits (e.g. Di Girolamo, 1970; Barberi et al., 1978; De Vivo et al., 2001; Fedele et al., 2008; Fisher et al., 1993; Melluso et al., 1995; Perrotta and Scarpati, 1994; Rosi et al., 1996; Scarpati and Perrotta, 2012). The lithology and depositional characteristics (lithofacies) of the CI change both laterally and vertically, especially due to variations in emplacement mechanisms, degree of welding and post-depositional processes (i.e. glass recrystallization and zeolitization). This gives origin to the superposition of different units, with different areal distribution and large variability from proximal to distal sites. Along and close to the caldera rims, the CI deposits occur in scattered outcrops (Fig. 1) mainly representing the proximal facies of this formation. Some authors have called these deposits the "Breccia Museo sequence" (Fedele et al., 2008 and references therein) identifying six stratigraphic units, which also include the usually distal lapilli fall basal layers (Appendix A). From the bottom to the top, this sequence is composed of: 1) plinian pumice fall deposit (PPF), including both the upper and the lower fallout unit of Signorelli et al. (1999); 2) unconsolidated stratified ash flow (USAF); 3) welded grey ignimbrite (WGI); 4) lower pumice flow unit (LPFU); 5) coarse lithic breccia (BU) sometimes interlayered with welded spatter beds (SU); 6) upper pumice flow unit (UPFU). In our study we refer to the stratigraphic units of Fedele et al. (2008), noting that they can be easily correlated to the ones 
previously identified by Rosi et al. (1996) (units A-D). Based on the position of the breccia unit (BU) within the sequence, the climactic caldera collapse likely occurred in the late phases of the CI eruption after the deposition of the main ignimbritic body (WGI and LPFU). BU contains a variety of lithic fragments of country rocks, including hydrothermally altered volcanics and plutonic lithologies with abundant alkali-syenites. The units in the intermediate portion of the pyroclastic sequence (WGI, SU and partially LPFU) are welded and extensively affected by post-deposition glass recrystallization (Cappelletti et al., 2003). The composition of the CI juvenile clasts ranges from trachyte to phonolite (Fig. 2) with a mineralogy of feldspars, clinopyroxenes, biotites, oxides and accessory apatite (Civetta et al., 1997).

\section{Methods}

Juvenile clasts representative of different units attributed to the CI fallout layers (Signorelli et al., 1999) and proximal deposits (Breccia Museo; Fedele et al., 2008) were sampled from the well-characterized stratigraphic sections of Voscone (VOS1 and VOS2), Verdolino (VV0) and Procida Island (Punta della Lingua, PRO1-1, PRO1-3, PRO1-4 and Scotto di Carlo, PRO2-1) (Fig. 1, Appendix A). Samples were analyzed for bulk-rock major and trace elements by XRF and ICPMS respectively at ETH Zürich (for a detailed description of the methods see Appendix B).

Mineral phases and matrix glass were analyzed for major elements by EMPA at ETH Zürich and INGV Rome. The operating conditions were as follows: $15 \mathrm{kV}$ acceleration voltage, counting times of $20 \mathrm{~s}$ on the peaks and $10 \mathrm{~s}$ on the backgrounds, $20 \mathrm{nA}$ (clinopyroxene, feldspars and oxides) or $15 \mathrm{nA}$ (biotite and glass) beam current. A defocused beam $(20 \mu \mathrm{m})$ was used for feldspar, biotite and glass analyses in order to minimize alkali migration. Samples showing incipient or pervasive recrystallization of glass were excluded from glass analyses. Analyses were typically reproducible to $<5 \%$ for all major and minor elements. Trace element compositions of mineral phases and matrix glass were measured by LAICPMS at ETH Zürich using a $193 \mathrm{~nm}$ ArF Excimer laser from Resonetic coupled to a 
Thermo Element XR ICPMS. A spot size of $43 \mu \mathrm{m}$ was used for mineral analyses and reduced to $20 \mu \mathrm{m}$ for glass analyses; output energy of the laser beam was typically $\sim 3.5$ $\mathrm{J} / \mathrm{cm}^{2}$. The MATLAB-based SILLS software (Guillong et al., 2008) was used for data reduction using NIST612 and NIST610 external standards. USGS reference glass GSD-1G was used as secondary standard to monitor the accuracy of the instrument. For each data point appropriate major element concentrations from EPMA analyses were used as internal standards. Long-term laboratory reproducibility of homogeneous glass standards indicates precision significantly better than $5 \%$ for elements whose concentration was much greater (i.e. $2 x$ ) than the detection limit. The full datasets of bulk-rock, matrix glass and mineral chemistry (including standards) are reported in Appendix B.

Relative crystallinity has been estimated by means of X-ray powder diffraction at ETH Zürich using an AXS D8 Advance diffractometer equipped with a Lynxeye superspeed detector. Powdered samples were analyzed using $\mathrm{CuK} \alpha$ radiation generated at $40 \mathrm{kV}$ and $40 \mathrm{~mA}$. Scans were run at $5-90^{\circ} 2 \theta$ using a $0.02^{\circ}$ step size and $1 \mathrm{~s}$ dwell time. A calibration curve for crystallinity measurements was prepared by mixing crushed powders of a granite (representing $100 \%$ crystallinity) and a glass plate (representing $0 \%$ crystallinity). For a detailed description of the method see Rowe et al. (2012). A plutonic clast (PRO1-2) sampled from the BU at Punta della Lingua (Procida Island) and two other samples of known crystallinity (09-012 and 09-023 from Rowe et al., 2012) were used to test the calibration procedure (see Appendix B).

\section{Results}

\subsection{Bulk-rock and matrix glass}

New bulk-rock and matrix glass data were combined with those from the literature in order to cover the whole spectrum of geochemical variability displayed by the CI pyroclastics. Whenever possible the samples were attributed to the stratigraphic units identified by Fedele 
et al. (2008) (PPF, USAF, WGI, LPFU, SU, BU and UPFU) with the aim of investigating the compositional and crystallinity gradients along the CI pyroclastic sequence (Figs. 2,3).

As a whole, CI bulk-rock and matrix glass range in composition from trachyte to phonolite (Fig. 2). A relative increase in $\mathrm{SiO}_{2}$ and decrease in alkali content is observed in the most evolved compositions $\left(\mathrm{SiO}_{2}>61 \mathrm{wt} \%\right.$; Fig. 2), typically reflecting alkali loss due to low temperature fluid-rock interaction (Donoghue et al., 2008). The relative crystallinity increases from $\sim 5-6 \%$ at the base of the sequence (PPF) up to $37 \%$ at the top (UPFU). BU contains both crystal-rich pumices ( $\sim 36$ vol\% crystals) and crystal-poor obsidian clasts ( $\sim 6$ vol\% crystals) (Fig. 3). The welded units (WGI and SU) return very high bulk crystallinity ( 66 and 62 vol\% crystals, respectively), as expected for pyroclastic rocks affected by devitrification (Rowe et al., 2012). Nevertheless, when the crystallinity determined from groundmass separates is subtracted from the bulk crystallinity, the samples can be interpreted as crystalpoor ( $\sim 5$ and 6 vol\% crystals, respectively) consistent with petrographic observations of phenocrysts abundance (see Appendix B).

Bulk-rock major element data indicate that the least evolved compositions (i.e. D.I. $<80$; $\mathrm{MgO}>1 \mathrm{wt} \%$; $\mathrm{CaO}>3 \mathrm{wt} \%)$ are found exclusively in the upper part of the pyroclastic sequence (SU, BU and UPFU), whereas the most evolved compositions occur throughout the CI (Fig. 3a-d). SU and BU display the greatest compositional variations. The matrix glass composition is weakly correlated with the stratigraphic height, whereas the bulk-rock exhibits $\mathrm{CaO}, \mathrm{MgO}$ and $\mathrm{K}_{2} \mathrm{O}$ enrichments with increasing stratigraphic height (Fig. 3a-d). Trace element concentrations indicate that both bulk-rock and matrix glass in the crystal-rich units (BU pumice and UPFU) are remarkably enriched in $\mathrm{Sr}$, Ba and depleted in $\mathrm{Zr}$ compared to all the other units (Fig. 3e-g). Eu anomalies are positive (or slightly negative) in the bulk-rock and matrix glass of the crystal-rich units and negative in the crystal-poor units (Fig. 3h).

\subsection{Feldspars}

K-feldspar is abundant in all the studied units and occurs as euhedral crystals often forming mineral aggregates. High- $\mathrm{Na}_{2} \mathrm{O}$ sanidine crystals $\left(\mathrm{Or}_{49-64}\right)$ have been recognized only in the 
crystal-poor units (PPF, WGI and SU) and are characterized by relatively low $\mathrm{Ba}$ and $\mathrm{Sr}$ contents (Fig. 4a). Conversely, low $\mathrm{Na}_{2} \mathrm{O}$ sanidines $\left(\mathrm{Or}_{76-87}\right)$ are concentrated, with few exceptions, in the crystal-rich units (BU and UPFU) and show characteristic zonation patterns with single or multiple Ba-Sr-rich rims (> 18000 ppm and >3100 ppm, respectively; Fig. $4 a, c)$.

Subhedral and zoned bytownitic plagioclases $\left(\mathrm{An}_{80-87}\right)$ occur in $\mathrm{BU}$ and UPFU, whereas euhedral andesine to oligoclase $\left(\mathrm{An}_{26-33}\right)$, and subordinately labradorite $\left(\mathrm{An}_{67}\right)$, have been recognized in PPF (Fig. 4b,d). The concentration of Sr in plagioclase ranges from 3412 to 194 ppm and decreases with increasing anorthite content (An\%; Fig. 4b).

\subsection{Clinopyroxene}

Three types of clinopyroxenes have been identified based on textural and geochemical characteristics (Fig. 5). Type 1 commonly occurs as highly resorbed cores of clinopyroxene crystals (Fig. 5c, d). Type 1 composition is Mg-rich diopside $(\mathrm{Mg \#}=81-93)$ with slightly negative or absent $\mathrm{Eu}$ anomaly $\left(\mathrm{Eu} / \mathrm{Eu}^{*}=0.5-1\right)$ (Fig. 5a,b). Type 2 and type 3 frequently occur as rims surrounding type 1 clinopyroxene and contain abundant oxide and apatite inclusions (Fig. 5 c, d). Rare type 2 cores and type 3 rims have been recognized. Type 2 is Ferich diopside $(\mathrm{Mg} \#=65-75)$ with a well-defined negative Eu anomaly $\left(\mathrm{Eu} / \mathrm{Eu}^{*}=0.2-0.6\right)$ (Fig. 5a,b). Type 3 is intermediate to low-Mg diopside $(\mathrm{Mg} \#=70-80)$ with slightly negative to positive Eu anomaly $\left(\mathrm{Eu} / \mathrm{Eu}^{*}=0.7-1.1\right)($ Fig. 5a,b). Compared to the other two types, type 2 is significantly enriched in REE (Fig. 5b), whereas type 3 is enriched in $\mathrm{Sr}$ (up to $232 \mathrm{ppm}$ ). 


\subsection{Other mineral phases}

Biotite is euhedral and contains abundant melt, apatite and oxide inclusions. Most biotite crystals are homogenous in major element compositions $(\mathrm{Mg} \#=67-70)$, but few $\mathrm{Mg}$-rich cores $(\mathrm{Mg} \#=65-75)$ have been observed in WGI and PPF. Sr and Ba contents $(50-190 \mathrm{ppm}$ and $160-8000 \mathrm{ppm}$, respectively) tend to decrease from core to rim. Biotite crystals show very low REE content.

Euhedral magnetite crystals $\left(\mathrm{Usp}_{15-28}\right)$ have been recognized in all the studied units but are more abundant in PPF, BU and UPFU compared to WGI and SU. Usp $25-28$ crystals are present in PPF only, whereas Usp ${ }_{15-19}$ crystals are mostly concentrated in the crystal-rich units.

\subsection{Magma crystallization conditions}

Crystallization temperatures and magma water content were estimated using specifically calibrated clinopyroxene-liquid thermometers (Masotta et al., 2013) and K-feldspar-liquid hygrometers (Mollo et al., 2015), respectively. Crystal cores were compared to whole-rock compositions as representative of the early stage of crystal nucleation, whereas crystal rims were combined with coexisting matrix glasses, which approximate the composition of the residual melt during the final stage of the crystal growth (Putirka, 2008). Only bulk-rock-core pairs were used for the welded units (WGI and SU) due to the lack of preserved glass. The equilibrium conditions between mineral and melt compositions were determined by means of test for equilibrium based on clinopyroxene-liquid and K-feldspar-liquid exchange reactions (Mollo and Masotta, 2014; Mollo et al., 2015). Only equilibrium compositions were used as input data for temperature and water estimates.

Thermometric calculations indicate relatively low crystallization temperatures for clinopyroxene-liquid pairs in PPF $\left(879-949^{\circ} \mathrm{C}\right)$. Similar ranges have been obtained for WGI and SU (910-972 ${ }^{\circ} \mathrm{C}$ and $900-946{ }^{\circ} \mathrm{C}$ respectively), whereas BU and UPFU record the highest temperatures (945-1046 ${ }^{\circ} \mathrm{C}$ and $945-1070{ }^{\circ} \mathrm{C}$ respectively) (Fig. 6). The melt- $\mathrm{H}_{2} \mathrm{O}$ content varies between $\sim 4$ and $6 \mathrm{wt} \%$ in the crystal-poor units (PPF, WGI and SU) and between $\sim 3$ 
and $5 \mathrm{wt} \%$ in the crystal-rich units (BU and UPFU) (Fig. 6). Estimated temperatures and water contents are in good agreement with published values obtained by means of melt inclusion analyses (Marianelli et al., 2006; Signorelli et al., 1999) and thermodynamic modeling (Fowler et al., 2007).

Oxygen fugacity conditions have been estimated using the spinel-melt oxygen barometer of Ishibashi (2013) derived from the formulation of Ariskin and Nikolaev (1996) for the $\mathrm{Fe}^{2+}-$ $\mathrm{Fe}^{3+}$ partitioning between spinel and melt, and the model of Sack et al. (1980) relating the $\mathrm{Fe}^{3+} / \mathrm{Fe}^{2+}$ ratio and oxygen fugacity in silicate melt. Results indicate that magmas equilibrated at the buffering condition of $\sim$ QFM (quartz-fayalite-magnetite) +1 close to that estimated by Bohrson et al. (2006) for the thermodynamic modeling of major and trace element behavior in the CI.

\section{Discussions}

\subsection{Origin and importance of crystallinity gradients}

The well-known geochemical gradients of the CI have been suggested as resulting from processes dominated either by mixing between magmas derived from different sources (Arienzo et al., 2009; Signorelli et al., 1999) or by fractional crystallization coupled with small amounts of crustal contamination (Bohrson et al., 2006; Fowler et al., 2007; Fulignati et al., 2004; Melluso et al., 1995; Pappalardo et al., 2008; Pappalardo et al., 2002). The mixing hypothesis is mainly supported by the compositional and isotopic differences between the least and the most evolved erupted magmas (i.e. the trachytes show lower ${ }^{87} \mathrm{Sr} /{ }^{86} \mathrm{Sr}$ and higher ${ }^{143} \mathrm{Nd} /{ }^{144} \mathrm{Nd}$ compared to the phonolites; Civetta et al., 1997; Pappalardo et al., 2002; Arienzo et al., 2009). On the contrary geochemical and thermodynamic models favor a fractional crystallization-dominated scenario in which compositionally different magmas are genetically related (Fowler et al., 2007; Pappalardo et al., 2008). In this frame, the isotopic differences have been considered to derive from interactions of the most evolved magmas with 
hydrothermal fluids prior to the eruption (Civetta et al., 1997) or to assimilation of basement rocks (Bohrson et al, 2006; Fowler et al., 2007; Gebauer et al., 2014).

We show that the compositional variations of the CI are more pronounced in the bulk-rock compared to the glass, suggesting that geochemical gradients are amplified by the remarkable increase in crystallinity from the bottom to the top of the sequence (Fig. 3). We argue that magma mixing alone would affect the bulk-rock geochemistry without generating strong crystallinity gradients. Protracted fractional crystallization processes instead would promote crystal settling and accumulation in a mush zone sitting at the bottom of the magma chamber, with residual melt most efficiently extracted at an intermediate crystallinity stage (50-70\% crystals; Dufek and Bachmann, 2010). These highly evolved and buoyant melts would be able to pool at the top of the magma chamber, thus forming a crystal-poor and relatively volatilerich cap (Bachmann and Bergantz, 2004). In agreement with these mechanical arguments, the crystal-poor and water-rich phonolitic compositions of the CI have been suggested to derive from the trachytic parent after $\sim 60 \%$ crystallization involving mainly feldspars and smaller amounts of clinopyroxene, biotite, magnetite and apatite (Pappalardo et al., 2008). Indeed, the deep negative Eu anomalies, coupled with the very low $\mathrm{Sr}$ and $\mathrm{Ba}$ contents displayed by the crystal-poor samples, indicate that they underwent significant fractionation of feldspar, whereas the positive Eu anomalies and the high $\mathrm{Ba}$ and $\mathrm{Sr}$ contents in the crystal-rich units suggest feldspar accumulation (Fig. 3e,f,h). Increasing water content from the crystal-rich to the crystal-poor units is indicative of melt extraction after crystallization of mainly anhydrous phases (Fig. 6). Zr content increases from the crystal-rich to the crystal-poor units (Fig. 3g) due to its incompatible behavior (i.e. $\mathrm{Zr}$ stays in the melt in such zircon undersaturated alkaline magmas; Gebauer et al., 2014).

Normal zoning in clinopyroxene crystals (i.e. transition from Mg-rich type 1 cores to Fe-rich type 2 rims; Figs. 5d) and increase in REE content from core to rim (Fig. 5a,b) both support crystal growth along a liquid line of descent. Additionally, the decrease of $\mathrm{Eu} / \mathrm{Eu} *$ from type 1 cores to type 2 rims reflects crystallization from a melt which experienced progressive feldspar fractionation (Fig. 5a). 


\subsection{Partition coefficients in clinopyroxene and link to crystal accumulation}

Using clinopyroxene core and bulk-rock analyses, we have calculated the partition coefficients of REE and Y for the crystal-poor (PPF) and crystal-rich (UPFU) products $\left[D_{i}=\right.$ $(\mathrm{I})_{\mathrm{xls}} /(\mathrm{I})_{\text {melt }}$ on a weight basis]. In order to interpret our partitioning data, the lattice strain model of Blundy and Wood (1994) was employed, wherein partitioning of a substituent cation (radius $r_{i}$ in meters) onto a structural site is related to the site radius $\left(r_{0}\right)$, its apparent Young modulus ( $\mathrm{E}$ in $\mathrm{GPa}$ ), and the strain-free partition coefficient $\mathrm{D}_{0}$ for a fictive cation with radius $r_{0}$ :

$\mathrm{D}_{\mathrm{i}}=\mathrm{D}_{0} \exp \left(\left(-4 \pi \mathrm{EN}_{\mathrm{A}}\left[\mathrm{r}_{0} / 2\left(\mathrm{r}_{\mathrm{i}}-\mathrm{r}_{0}\right)^{2}+1 / 3\left(\mathrm{r}_{\mathrm{i}}-\mathrm{r}_{0}\right)^{3}\right]\right) /(\mathrm{RT})\right)$

where $\mathrm{N}_{\mathrm{A}}$ is Avogadro's number $\left(6.022 \times 10^{23} \mathrm{~mol}^{-1}\right), \mathrm{R}$ is the universal gas constant $(8.3145 \mathrm{~J}$ $\mathrm{mol}^{-1}$ ), and $\mathrm{T}$ is the temperature (in Kelvin degrees). The best-fit values for $\mathrm{D}_{0}$ (plotted as a function of temperature; Fig. 7a) show a good linear relationship between $\ln \mathrm{D}_{0}$ and $1 / \mathrm{T}$. Indeed, Wood and Blundy (1997) suggested that REE partition coefficients decrease with increasing temperature due to the positive entropy of fusion of silicate minerals. For clinopyroxenes with similar major cation proportions, McDade et al. (2003) found that $\ln \mathrm{D}_{0}$ increases linearly with $1 / \mathrm{T}$. This is confirmed by our regression fits yielding a significant dependence of the strain-free partition coefficient on temperature (Fig. 7a). However, assuming that PPF and UPFU liquids differentiated along the same evolutionary path (i.e. cogenetic origin), the occurrence of two distinct linear fits is not plausible. This is particularly true for the lattice strain model, which has the advantage of eliminating the effect of liquid composition on mineral-melt partitioning (e.g. Mollo et al., 2013 and references therein). According to thermodynamics, $\mathrm{D}_{0}$ values derived for UPFU should be much lower than those derived for PPF (i.e. $\ln \mathrm{D}_{0}$ increases with increasing $1 / \mathrm{T}$ ). Additionally, $\mathrm{D}_{0}(0.854-3.236)$ values measured for PPF closely match with those (0.701-3.549) from previous studies on trachy-phonolitic magmas of Campi Flegrei (Fedele et al., 2009; Mollo et al., 2016; 
Pappalardo et al., 2008), in contrast $\mathrm{D}_{0}(0.165-0.935)$ values measured for UPFU are remarkably low. This discrepancy is best resolved if the magma from which clinopyroxene crystallized was different and more evolved (higher REE and Y concentrations) than the UPFU bulk-rock composition. When the concentrations of REE and Y measured for UPFU are normalized to those measured for PPF (Fig. 7b), the observed Eu enrichment and the overall trace element depletion clearly indicate feldspar and clinopyroxene accumulation (Fig. 7b). Consequently, the higher values of $D_{\text {REE }+Y}$ measured for UPFU can be interpreted as apparent partition coefficients due to disequilibrium processes caused by clinopyroxene and feldspar accumulation in parts of the magma reservoir. In those regions, the bulk composition of the cumulate deviates from the geochemical evolution of the CI magma, providing explanation for the mismatch between $\mathrm{D}_{0}$ values measured for UPFU and PPF.

\subsection{Origin of geochemical and thermal gradients}

As discussed above, the geochemical gradients observed in the bulk-rock geochemistry are strongly controlled by crystallinity variations induced by crystal/melt separation, and accumulation of crystallizing mineral phases in different regions of the reservoir. However glass compositions also show peculiar geochemical variations, which correlate well with stratigraphic height (i.e. upward enrichment of $\mathrm{Sr}, \mathrm{Ba}$ and $\mathrm{Eu} / \mathrm{Eu}^{*}$ and depletion of $\mathrm{Zr}$; Fig. 3e-h, 8). Additionally, clinopyroxene geothermometry indicate increasing temperatures towards the top of the pyroclastic sequence (i.e. from the crystal-poor to the crystal-rich units; Fig. 6), reflecting a vertical thermal gradient within the magma chamber. Moreover, the presence of slightly negative to positive Eu anomalies in type 3 clinopyroxene (Fig. 5), together with $\mathrm{Ba}$ and Sr-rich feldspar rims (Fig. 4a,c) requires the occurrence of other processes than a simple cooling trend, generating crystal fractionation.

A possible hypothesis is that type 3 clinopyroxene and feldspar rims result from interaction with a less differentiated melt during the late stages of crystal growth. Indeed, hotter and more mafic recharge has often been implicated as a potential trigger for the CI eruption (e.g. Arienzo et al., 2009; Signorelli et al., 1999) and is also supported by the occurrence of An- 
rich plagioclase $\left(\mathrm{An}_{80-87}\right.$, in clear disequilibrium with the $\mathrm{CI}$ melts) and by the thermal gradient revealed by clinopyroxene thermometry. The more mafic magmas that were erupted at Campi Flegrei caldera during the post-collapse activity typically show high $\mathrm{Ba}$ and $\mathrm{Sr}$ contents ( 1800 and 1000 ppm, respectively; D'Antonio et al., 1999). However, these magmas are crystal-poor and display slightly negative Eu anomalies, indicative of feldspar fractionation (mainly An-rich plagioclase containing relatively low Sr). Moreover, the interaction with such mafic magmas (basaltic trachy-andesites with Mg\#= 50-60; D'Antonio et al., 1999) would lead to the crystallization of higher-Mg\# ( 83-86) clinopyroxene rims compared to the $\mathrm{Mg} \#(<80)$ of type 3 clinopyroxene. The Mg number of clinopyroxene in equilibrium with a basaltic trachy-andesitic melt was calculated using bulk-rock compositions from D'Antonio et al. (1999). Equilibrium conditions are in the range $\mathrm{K}_{\mathrm{D}}(\mathrm{Fe}-\mathrm{Mg})^{\mathrm{cpx}-\mathrm{liq}}=$ $0.27 \pm 0.03$ (Putirka, 2008).

We conclude that either fractional crystallization or mixing induced by mafic recharge alone cannot account for the complex features displayed by the CI. We suggest that the injection of mafic magma occurred at the base of the magma chamber, but could not propagate much further, due to the density contrast between the recharge and the resident magma (Wolff et al., 2015). This injection of hot magma within the cumulate pile likely affected the stability of the low temperature mineral phases (i.e. feldspars) triggering the partial melting of these phases and the formation of melts locally enriched in $\mathrm{Ba}, \mathrm{Sr}$ and $\mathrm{Eu}$ from which sanidine and type 3 clinopyroxene could re-crystallize. Testimony of the existence of $\mathrm{Ba}, \mathrm{Sr}$ and Eu-rich melts comes from glass compositions within the crystal-rich units (Figs. 3, 8). It has to be noted that partial melting of the cumulate pile is essential to reduce the crystallinity of the cumulate mush making it rheologically eruptible ( $<50 \%$ crystals; Huber et al., 2012).

\subsection{A geochemical model for crystal accumulation, melt extraction and cumulate melting}

Since fractional crystallization is the dominant process governing the evolution of the CI magma, we have performed fractional crystallization (FC) and fractional crystallization and assimilation (AFC) models using $\mathrm{Ba}$ and $\mathrm{Zr}$ as representative compatible and incompatible 
elements in our system (Fig. 9a). Indeed, Ba is compatible in both biotite and sanidine, while $\mathrm{Zr}$ is incompatible with any of the major or accessory phases observed in the $\mathrm{CI}$ juvenile clasts. Although zircon crystals have been observed in syenite blocks within BU, they are often interstitial, indicating very late crystallization (Gebauer et al., 2014); therefore we assume zircon does not become stable until the system is essentially at its solidus. Based on these observations and on the partition coefficients reported in the literature for the Campi Flegrei magmas (Pappalardo et al., 2008), we have chosen a bulk-rock Kd of 4.3 and 0.05 for $\mathrm{Ba}$ and $\mathrm{Zr}$ respectively. In the $\mathrm{AFC}$ model an assimilation/fractional crystallization ratio (R) of 0.1 has been used according to Pappalardo et al. (2008). Both FC and AFC models show that fractional crystallization of more than $70-80 \%$ of the least evolved compositions (relatively high-Ba and low-Zr) would be required to match the most evolved compositions (Fig. 9a). Such values are significantly in excess of those obtained by means of mass balance calculations ( $60 \%$; Pappalardo et al., 2008). Moreover they seem to be quite unrealistic due to the very low segregation rates, which would prevent the separation of crystal-poor silicic melts from such high crystalline solid residue on reasonable geologic timescales (Bachmann and Bergantz, 2004).

Therefore we conclude that neither simple FC nor AFC models are suitable for describing in full the behavior of trace elements in the CI magma. For this reason we applied the model proposed by Gelman et al. (2014), which describes the behavior of trace elements in a magma mush environment. This method assumes fractional crystallization within the mush, even though crystals and melt may remain adjacent to each other. This assumption is justified as long as chemical diffusion of the trace element is slow relative to the timescales of crystal/melt segregation. Overprinted on this mush crystallization model is the additional effect of melt loss out of the mush and incremental accumulation into a melt-rich cap (see Appendix $\mathrm{C}$ for a detailed description of the method). Necessary inputs to the model include: initial concentrations of each trace element in the 'parent' magma, bulk-rock partition coefficients and the rate and amount of melt which is segregated from the mush. The method allows both the partition coefficient and rate of melt segregation to be functions of 
crystallinity. For this model, we have chosen a range of bulk partition coefficient. For the melt segregation rate, we follow the results from Dufek and Bachmann (2010) and use a Gaussian curve centered on intermediate mush crystallinity (see Appendix C).

Our model shows that calculated cumulate compositions are very similar to the population of initial compositions, while the calculated segregated melts present highly fractionated geochemical signatures (Fig. 9b). A clear compositional gap is generated between the populations of modeled segregated melts and cumulates. While the CI data tend to cluster in the same general $\mathrm{Zr}-\mathrm{Ba}$ compositional space, there is additional scatter in the natural data, linking the populations into an apparently more continuous trend (Fig. 9a). We argue that remelting of the cumulate occurring during reheating/rejuvenation processes following recharge, without large degrees of mass transfer from the more mafic magma to the resident magma (Wolff et al., 2015) in responsible for this continuous trend. To illustrate this effect, we modeled a partial remelting event of the calculated cumulate compositions. We assumed slightly elevated partition coefficients for both $\mathrm{Zr}$ and $\mathrm{Ba}$ (see Appendix $\mathrm{C}$ ), since presumably feldspars are the modally dominant minerals involved in the melting, and because zircon may begin to become stable near the solidus (Gebauer et al., 2014). As shown in Fig. 9b, this partial remelting effectively 'fills in' the compositional gap formed during the downtemperature fractionation modeling.

\subsection{Stability of the mineral phases}

Important constraints on the stability of mineral phases from the $\mathrm{CI}$ at water-saturated conditions were obtained experimentally by Fabbrizio and Carroll (2008). Crystallization experiments, conducted using the composition of a crystal-rich pumice from UPFU, indicate that magnetite and biotite are the liquidus phases followed by clinopyroxene $\left(>880^{\circ} \mathrm{C}\right.$ at 200 MPa). Sanidine and plagioclase by contrast become stable at much lower temperatures $\left(800^{\circ} \mathrm{C}\right.$ and $770^{\circ} \mathrm{C}$ at $\left.200 \mathrm{MPa}\right)$.

In agreement with these experimental data, we observe that the high-temperature mineral phases (magnetite and biotite) record a coherent cooling trend, with magnetite evolving from 
Ti-poor to Ti-rich compositions and biotite crystals mostly showing a decrease in $\mathrm{Sr}$ and $\mathrm{Ba}$ towards the rims. These features, together with the absence of disequilibrium textures in magnetite and biotite, confirm that these mineral phases were relatively refractory in the CI system and remain undisturbed (i.e. did not participate to any significant extent in the cumulate melting and associated re-crystallization; Fig. 10). The partial melting of the cumulate mush following mafic recharge mainly affected the feldspars $( \pm$ Fe-rich clinopyroxene; Fig. 10). The lack of low-An plagioclase crystals within the crystal-rich units while occurring in the crystal-poor juveniles, indicate extensive melting of this phase within the cumulate mush. We note that $\mathrm{Sr}$ and Ba-rich sanidine rims are only present within the crystal-rich units, whereas type 3 clinopyroxene occurs within both the crystal-rich and the crystal-poor units (Figs. 4,5). We suggest that some type 3 clinopyroxene, which likely crystallized within the cumulate mush at higher temperatures compared to the sanidine rims, might have been entrained within the crystal-poor region by convection currents. Indeed, partial melting due to hotter recharge certainly lowered the crystallinity of the mush triggering dynamic stirring in the crystal-poor magma (Fig. 10). Sanidine rims likely crystallized within the cumulate mush, when convection had already ceased, hampering mass transfer from the crystal-rich to the crystal-poor region (Fig. 10).

\section{Conclusions}

The CI pyroclastic succession represents the inversion of a chemically zoned magma chamber showing remarkable crystallinity, compositional and thermal gradients. In agreement with previous studies of other zoned ignimbrites (see recent reviews from Wolff et al., 2015 and Evans et al., 2016), we propose a refined model for the generation of gradients in the CI. Our model suggests that the subvolcanic magma reservoir below the Campi Flegrei region evolved, by incremental addition of deeper recharge, into a high-crystallinity region (i.e. crystal mush), from which crystal-poor melts were extracted, forming an easily eruptible cap at the top of the reservoir (Fig. 10), particularly in this volatile-rich environment where bubbles tend to accumulate in the crystal-poor zone (e.g. Parmigiani et al., 2016). The crystal- 
poor cap fed the initial stages of the eruption characterized by a plinian phase, which deposited fallout layers (PPF), followed by the development of pyroclastic density currents generating the main ignimbritic body (LPFU, WGI). During this latter phase, large volumes of magma were evacuated, triggering caldera collapse. The crystal-rich magma was erupted during the last phases of the eruption, accumulating in the proximal areas (BU and UPFU). We suggest that the crystal-rich units represent remobilized and partially remelted portions of the cumulate mush, rejuvenated after more mafic recharge (Fig. 10). Due to density and rheological contrasts between the invading and the resident magmas, the propagation of the more mafic magma was typically inhibited, and cumulate remelting likely occurred without significant mass transfer. This explains the absence in the erupted material of mafic enclaves akin to the recharge magma. Several lines of evidence, not yet taken into account in previous studies, support our interpretation: 1) the relatively high temperatures recorded by the crystalrich units, indicative of heat transfer from a hotter magma; 2) the positive Eu anomalies in the matrix glass of the crystal-rich units, testifying to the presence of liquid derived from partial melting of the low temperature phases within the cumulate pile; 3) the Ba-Sr-rich rims in the feldspars and the positive Eu anomalies in clinopyroxene (type 3), implying late crystalgrowth from the cumulate melting-derived liquid; 4) the mismatch between $\mathrm{D}_{0}$ values derived for the crystal-rich and crystal-poor units, revealing that the crystal-rich bulk compositions do not represent the parental liquid to the most evolved melt, but rather cumulative compositions; and 5) the An-rich plagioclase recording the occurrence of mafic recharge, leading to cumulate melting.

We conclude that crystal accumulation and efficient melt extraction, followed by cumulate melting and remobilization, represent the main processes responsible for the generation of gradients in the CI, and is likely generalizable to other zoned ignimbrites worldwide. Such processes have been increasingly recognized in the evolution of large silicic bodies (e.g. Crater Lake, Bacon and Druitt, 1988; Ammonia Tank Tuff, Deering et al., 2011; Carpenter Ridge Tuff, Bachmann et al., 2014; Bandelier Tuff, Wolff and Ramos, 2014; Arico ignimbrite, Sliwinski et al., 2015), and can reconcile models advocating pure mixing between 
magmas of different origin and composition (e.g. Arienzo et al., 2009; Eichelberger et al., 2000; Troll and Schmincke, 2002) with those putting more emphasis on in-situ fractional crystallization (e.g. Hildreth and Fierstein, 2000; Pappalardo et al., 2008; Worner and Schmincke, 1984). We propose a fractional crystallization-dominated scenario, in which preeruptive mixing with hotter recharge is essential to remobilize portions of the cumulate mush. In this framework, the example of the CI makes a particularly compelling case in a young, still active system.

\section{Acknowledgments}

We would like to thank Lukas Martin and Marcel Guillong for their precious assistance during the microprobe and laser analyses and Dina Klimentyeva for helping during petrographic analyses. We are grateful to John Wolff and Dawid Szymanowski for thoughtful discussions, which helped us to improve the manuscript. We express our gratitude to Lucia Pappalardo and an anonymous referee for constructive reviews and to Tamsin Mather for the editorial efforts. This project has been supported by Swiss National Science Foundation grant 200021_146268 to Olivier Bachmann.

\section{Figures}

Fig. 1 Schematic map showing the distribution of the pyroclastic fallout and flow deposits referred to the Campanian Ignimbrite $(\mathrm{CI})$ eruption, the distribution of the Breccia Museo deposits (modified after Fulignati et al., 2004) and the sampling localities.

Fig. 2 Total alkali-silica classification diagram (after Perrotta and Scarpati, 1994) showing the composition of bulk-rock (=closed symbols) and matrix glass (=open symbols; average glass analyses) of the CI. Data from this paper are indicated using colored symbols. Grey symbols refer to literature data (TAS; Le Bas et al., 1986). Whenever possible the literature data were 
attributed to the stratigraphic units defined by Fedele et al. (2008), otherwise they were indicated as "other CI". Data are reported on an anhydrous basis.

Fig. 3 Variation diagrams of D.I. (=Q+Or+Ab+Ne+Lc normative) and selected major and trace elements vs. stratigraphic position for bulk-rock (=closed symbols) and average glass analyses (=open symbols). Colored symbols refer to data from this study, whereas grey symbols indicate data from the literature (same references as in Fig. 2). Whenever possible the literature data were attributed to the stratigraphic units defined by Fedele et al. (2008), otherwise they were indicated as "other CI". Numbers indicate the calculated relative crystallinity of corresponding samples. $\mathrm{Eu} / \mathrm{Eu}^{*}=\mathrm{Eu}_{N} /\left(\mathrm{Sm}_{N} \times \mathrm{Gd}_{\mathrm{N}}\right)^{1 / 2}$. Data are reported on an anhydrous basis.

Fig. 4 Sr vs. Ba diagrams (a, b) and back-scattered images (c, d) of feldspars from the CI. Classification diagrams are shown in the insets. Sanidine crystals display an increase of $\mathrm{Ba}$ and $\mathrm{Sr}$ content towards the crystal rims in the crystal-rich units (BU and UPFU) (a), which is also indicated by the bright rims in the back-scattered images (c). Plagioclase crystals display an increase of $\mathrm{Sr}$ and $\mathrm{Ba}$ with anorthite content (b). Bytownitic plagioclase, likely derived from a more mafic recharge, is typically subhedral (d). Samples were attributed to the stratigraphic units recognized in the type-section of the Breccia Museo pyroclastic sequence (Arienzo et al., 2009; Civetta et al., 1997; Fedele et al., 2008; Fulignati et al., 2004; Marianelli et al., 2006; Melluso et al., 1995; Pappalardo et al., 1999; Pappalardo et al., 2008; Pappalardo et al., 2002; Polacci et al., 2003; Signorelli et al., 1999).

Fig. $5 \mathrm{Eu} / \mathrm{Eu}^{*}\left[=\mathrm{Eu}_{N} /\left(\mathrm{Sm}_{\mathrm{N}} \times \mathrm{Gd}_{\mathrm{N}}\right)^{1 / 2}\right]$ vs. $\mathrm{Mg} \#[=(\mathrm{Mg} /(\mathrm{Mg}+\mathrm{Fe}) \times 100]$ diagram (a) and chondrite-normalized REE patterns (b) of clinopyroxene crystals from the CI showing the three different types of crystals and the distribution of these three types in the stratigraphic units recognized in the type-section of the Breccia Museo pyroclastic sequence (after Fedele 
et al., 2008). In (a), arrows indicate the core-rim connections in the studied clinopyroxene crystals and shown in the backscattered images: clinopyroxene crystals showing type 1 cores with type 2 (c) and type 3 (d) rims. Chondrite compositions are from (after Fedele et al., 2008).

Fig. 6 Temperature $\left({ }^{\circ} \mathrm{C}\right.$ ) in filled boxes and $\mathrm{H}_{2} \mathrm{O}$ content (wt $\%$ ) in empty boxes calculated for the different stratigraphic units using the geothermometer of Masotta et al. (2013) and the hygrometer of Mollo et al. (2015), respectively. A pressure of 2.5 kbar (Pappalardo et al., 2008) and melt-water content of $5 \mathrm{wt} \%$ were used for the thermometric calculations. It has to be noted that the estimated temperatures obtained by changing the water content by $2 \mathrm{wt} \%$ are included within the error of the method. A temperature of $883{ }^{\circ} \mathrm{C}$ (feldspars crystallization temperature according to Fowler et al., 2001) was used for the hygrometric calculations.

Fig. 7 Comparison of $\operatorname{lnD}_{0}$ values for clinopyroxene-melt partitioning of $\mathrm{REE}+\mathrm{Y}$ plotted versus $1 / T$. $\mathrm{D}_{0}$ is calculated by the lattice strain model of Blundy and Wood (1994). According to thermodynamics, $\ln \mathrm{D}_{0}$ increases linearly with $1 / \mathrm{T}$. However, the two linear fits for UPFU and PPF apparently preclude a cogenetic origin. See text for more explanation.

Fig. 8 Chondrite-normalized REE patterns of matrix glass from the CI showing relatively high REE content and negative Eu anomalies in the glass from the crystal-poor units (PPF and BU obsidian) and lower REE content and slightly negative to positive Eu anomalies in the glass from the crystal-rich units (BU pumice and UPFU). Chondrite compositions are from Mcdonough and Sun (1995).

Fig. $9 \mathrm{Zr}$ vs. Ba plots showing classical FC and AFC geochemical modeling (a) and trace element modeling for crystal accumulation, melt extraction and cumulate melting obtained using the method of Mcdonough and Sun (1995) (b). In (a), fixed values of partition coefficients, assimilant composition and assimilation/fractionation crystallization ratio (R) 
have been chosen according to Gelman et al. (2014). Symbols along the lines refer to melt fraction (F) with steps of 0.1. Data from this paper are indicated using colored symbols. Grey symbols refer to literature data (same references as in Fig. 2). Whenever possible the literature data were attributed to the stratigraphic units defined by Fedele et al. (2008), otherwise they were indicated as "other CI". In (b), random normally-distributed populations for each input parameter (initial compositions, partition coefficients and melt segregation rate) were used to simulate the compositions of cumulates, segregated melt and partially remelted cumulates (see section 5.3 and Appendix C for more information).

Fig. 10 Schematic cartoon illustrating the main processes involved in the generation of gradients in the CI (modified after Wolff et al., 2015). Step 1 shows magma evolution through fractional crystallization and consequent generation of a cumulate crystal mush at the bottom of the magma chamber and a solidification front at the roof. When the crystallinity reaches $\sim 50-70 \%$ crystals, crystal-poor and evolved melts are efficiently extracted from the crystalrich region and form a buoyant cap at top of the chamber (development of a geochemical and crystallinity gradient; Fig. 3). At this stage the cumulate mush is mainly composed of sanidine, plagioclase, clinopyroxene (type 1 and 2), biotite, magnetite and apatite, and is rheologically locked. Step 2 depicts the effect of mafic recharge on the stability of mineral phases: plagioclase and sanidine undergo extensive melting, generating a liquid locally enriched in $\mathrm{Sr}, \mathrm{Ba}$ and $\mathrm{Eu}$ (Figs. 3, 8), from which type 3 clinopyroxene recrystallize (Fig. 5). After partial melting, the crystallinity of the cumulate mush is sensibly reduced, triggering convection within the crystal-poor cap. This allows crystals from the mush (e.g. type 3 clinopyroxene) to move upwards in the crystal-poor region. At this stage the temperature in the lower part of the magma chamber is much higher than in the crystal-poor lens (development of a thermal gradient; Fig. 6). In step 3 high-Sr-Ba sanidine rims (Fig. 4) crystallize from the enriched melt at lower temperature and remain confined in the crystalrich region. Convection in the crystal-poor cap is now much lower due to the smaller temperature gradient and the increase in crystallinity. 


\section{References}

Arienzo, I., Civetta, L., Heumann, A., Worner, G., Orsi, G., 2009. Isotopic evidence for open system processes within the Campanian Ignimbrite (Campi FlegreiItaly) magma chamber. Bulletin of Volcanology 71, 285-300.

Ariskin, A.A., Nikolaev, G.S., 1996. An empirical model for the calculation of spinel melt equilibria in mafic igneous systems at atmospheric pressure .1. Chromian spinels. Contrib Mineral Petr 123, 282-292.

Bachmann, O., Bergantz, G.W., 2003. Rejuvenation of the Fish Canyon magma body: A window into the evolution of large-volume silicic magma systems. Geology 31, 789-792.

Bachmann, O., Bergantz, G.W., 2004. On the origin of crystal-poor rhyolites: Extracted from batholithic crystal mushes. J Petrol 45, 1565-1582.

Bachmann, O., Bergantz, G.W., 2008. Deciphering Magma Chamber Dynamics from Styles of Compositional Zoning in Large Silicic Ash Flow Sheets. Rev Mineral Geochem 69, 651-674.

Bachmann, O., Deering, C.D., Lipman, P.W., Plummer, C., 2014. Building zoned ignimbrites by recycling silicic cumulates: insight from the 1,000 km(3)

Carpenter Ridge Tuff, CO. Contrib Mineral Petr 167.

Bacon, C.R., Druitt, T.H., 1988. Compositional evolution of the zoned calcalkaline magma chamber of Mount Mazama, Crater Lake, Oregon. Contrib Mineral Petr 98, 224-256.

Barberi, F., Innocenti, F., Lirer, L., Munno, R., Pescatore, T., Santacroce, R., 1978. The campanian ignimbrite: a major prehistoric eruption in the Neapolitan area (Italy). Bull Volcanol 41, 10-31.

Bindeman, I.N., Valley, J.W., 2003. Rapid generation of both high- and low-delta 0-18, large-volume silicic magmas at the Timber Mountain/Oasis Valley caldera complex, Nevada. Geol Soc Am Bull 115, 581-595.

Blundy, J., Wood, B., 1994. Prediction of Crystal-Melt Partition-Coefficients from Elastic-Moduli. Nature 372, 452-454.

Bohrson, W.A., Spera, F.J., Fowler, S.J., Belkin, H.E., De Vivo, B., Rolandi, G., 2006. Petrogenesis of the Campanian Ignimbrite: implications for crystal-melt separation and open-system processes from major and trace elements and Th isotopic data. Volcanism in the Campania Plain: Vesuvius, Campi Flegrei and Ignimbrites 9, 249-288.

Cappelletti, P., Cerri, G., Colella, A., de'Gennaro, M., Langella, A., Perrotta, A., Scarpati, C., 2003. Post-eruptive processes in the Campanian Ignimbrite. Miner Petrol 79, 79-97.

Civetta, L., Orsi, G., Pappalardo, L., Fisher, R.V., Heiken, G., Ort, M., 1997. Geochemical zoning, mingling, eruptive dynamics and depositional processes The Campanian Ignimbrite, Campi Flegrei caldera, Italy. Journal of Volcanology and Geothermal Research 75, 183-219.

D'Antonio, M., 2011. Lithology of the basement underlying the Campi Flegrei caldera: Volcanological and petrological constraints. Journal of Volcanology and Geothermal Research 200, 91-98.

D'Antonio, M., Civetta, L., Orsi, G., Pappalardo, L., Piochi, M., Carandente, A., de Vita, S., Di Vito, M.A., Isaia, R., 1999. The present state of the magmatic system of the Campi Flegrei caldera based on a reconstruction of its behavior in the past 12 ka. Journal of Volcanology and Geothermal Research 91, 247-268. 
de Silva, S.L., 1991. Styles of zoning in central Andean ignimbrites; Insights into magma chamber processes. Geological Society of America Special Papers 265, 217-232.

De Vivo, B., Rolandi, G., Gans, P.B., Calvert, A., Bohrson, W.A., Spera, F.J., Belkin, H.E., 2001. New constraints on the pyroclastic eruptive history of the Campanian volcanic Plain (Italy). Miner Petrol 73, 47-65.

Deering, C.D., Bachmann, O., Vogel, T.A., 2011. The Ammonia Tanks Tuff:

Erupting a melt-rich rhyolite cap and its remobilized crystal cumulate. Earth Planet Sc Lett 310, 518-525.

Deino, A.L., Orsi, G., de Vita, S., Piochi, M., 2004. The age of the Neapolitan Yellow Tuff caldera-forming eruption (Campi Flegrei caldera Italy) assessed by Ar40/Ar-39 dating method. Journal of Volcanology and Geothermal Research 133, 157-170.

Di Vito, M., Lirer, L., Mastrolorenzo, G., Rolandi, G., 1987. The 1538 Monte Nuovo eruption (Campi Flegrei, Italy). Bulletin of Volcanology 49, 608-615.

Di Vito, M.A., Isaia, R., Orsi, G., Southon, J., de Vita, S., D'Antonio, M., Pappalardo, L., Piochi, M., 1999. Volcanism and deformation since 12,000 years at the Campi Flegrei caldera (Italy). Journal of Volcanology and Geothermal Research 91, 221246.

Donoghue, E., Troll, V.R., Harris, C., O'Halloran, A., Walter, T.R., Torrado, F.J.P., 2008. Low-temperature hydrothermal alteration of intra-caldera tuffs, Miocene Tejeda caldera, Gran Canaria, Canary Islands. Journal of Volcanology and Geothermal Research 176, 551-564.

Dorais, M.J., Whitney, J.A., Stormer, J.C., 1991. Mineralogical Constraints on the Petrogenesis of Trachytic Inclusions, Carpenter Ridge Tuff, Central San-Juan Volcanic Field, Colorado. Contrib Mineral Petr 107, 219-230.

Dufek, J., Bachmann, 0., 2010. Quantum magmatism: Magmatic compositional gaps generated by melt-crystal dynamics. Geology 38, 687-690.

Eichelberger, J.C., Chertkoff, D.G., Dreher, S.T., Nye, C.J., 2000. Magmas in collision: Rethinking chemical zonation in silicic magmas. Geology 28, 603-606. Evans, B.W., Hildreth, W., Bachmann, O., Scaillet, B., 2016. In defense of magnetite-ilmenite thermometry in the Bishop Tuff and its implication for gradients in silicic magma reservoirs. American Mineralogist 101, 469-482. Fabbrizio, A., Carroll, M.R., 2008. Experimental constraints on the differentiation process and pre-emptive conditions in the magmatic system of Phlegraean Fields (Naples, Italy). Journal of Volcanology and Geothermal Research 171, 88-102. Fedele, L., Scarpati, C., Lanphere, M., Melluso, L., Morra, V., Perrotta, A., Ricci, G., 2008. The Breccia Museo formation, Campi Flegrei, Southern Italy:

Geochronology, chemostratigraphy and relationship with the Campanian Ignimbrite eruption. Bulletin of Volcanology 70, 1189-1219.

Fedele, L., Zanetti, A., Morra, V., Lustrino, M., Melluso, L., Vannucci, R., 2009. Clinopyroxene/liquid trace element partitioning in natural trachytetrachyphonolite systems: insights from Campi Flegrei (southern Italy). Contrib Mineral Petr 158, 337-356.

Fisher, R.V., Orsi, G., Ort, M., Heiken, G., 1993. Mobility of a Large-Volume Pyroclastic Flow - Emplacement of the Campanian Ignimbrite, Italy. Journal of Volcanology and Geothermal Research 56, 205-220. 
Fowler, S.J., Spera, F., Bohrson, W., Belkin, H.E., De Vivo, B., 2007. Phase equilibria constraints on the chemical and physical evolution of the campanian ignimbrite. J Petrol 48, 459-493.

Fulignati, P., Marianelli, P., Proto, M., Sbrana, A., 2004. Evidences for disruption of a crystallizing front in a magma chamber during caldera collapse: an example from the Breccia Museo unit (Campanian Ignimbrite eruption, Italy). Journal of Volcanology and Geothermal Research 133, 141-155.

Gebauer, S.K., Schmitt, A.K., Pappalardo, L., Stockli, D.F., Lovera, O.M., 2014. Crystallization and eruption ages of Breccia Museo (Campi Flegrei caldera, Italy) plutonic clasts and their relation to the Campanian ignimbrite. Contrib Mineral Petr 167, 1-18.

Gelman, S.E., Deering, C.D., Bachmann, O., Huber, C., Gutiérrez, F.J., 2014. Identifying the crystal graveyards remaining after large silicic eruptions. Earth Planet Sc Lett 403, 299-306.

Guillong, M., Meier, D.L., Allan, M.M., Heinrich, C.A., Yardley, B.W.D., 2008. SILLS: a MATLAB-based program for the reduction of laser ablation ICP-MS data of homogeneous materials and inclusions. Short Course Notes - Geol. Assoc. Can. 40, 328-333.

Hervig, R.L., Dunbar, N.W., 1992. Cause of Chemical Zoning in the Bishop (California) and Bandelier (New-Mexico) Magma Chambers. Earth Planet Sc Lett 111, 97-108.

Hildreth, W., 1981. Gradients in Silicic Magma Chambers - Implications for Lithospheric Magmatism. J Geophys Res 86, 153-192.

Hildreth, W., 2004. Volcanological perspectives on Long Valley, Mammoth Mountain, and Mono Craters: several contiguous but discrete systems. Journal of Volcanology and Geothermal Research 136, 169-198.

Hildreth, W., Fierstein, J., 2000. Katmai volcanic cluster and the great eruption of 1912. Geol Soc Am Bull 112, 1594-1620.

Huber, C., Bachmann, O., Dufek, J., 2012. Crystal-poor versus crystal-rich ignimbrites: A competition between stirring and reactivation. Geology 40, 115118.

Ishibashi, H., 2013. Spinel-melt oxygen barometry: amethod and application to Cenozoic alkali basaltic magmas from the Higashi-Matsuura district, NW Kyushu, Japan. Geosci. Repts. 40, 21-32.

Le Bas, M.J., Le Maitre, R.W., Streckeisen, A., Zanettin, B., Rocks, I.S.o.t.S.o.I., 1986. A Chemical Classification of Volcanic Rocks Based on the Total Alkali-Silica Diagram. J Petrol 27, 745-750.

Lipman, P.W., 1971. Iron-Titanium Oxide Phenocrysts in Compositionally Zoned Ash-Flow Sheets from Southern Nevada. J Geol 79, 438-456.

Marianelli, P., Sbrana, A., Proto, M., 2006. Magma chamber of the Campi Flegrei supervolcano at the time of eruption of the Campanian Ignimbrite. Geology 34, 937-940.

Masotta, M., Mollo, S., Freda, C., Gaeta, M., Moore, G., 2013. Clinopyroxene-liquid thermometers and barometers specific to alkaline differentiated magmas. Contrib Mineral Petr 166, 1545-1561.

McDade, P., Blundy, J.D., Wood, B.J., 2003. Trace element partitioning between mantle wedge peridotite and hydrous MgO-rich melt. American Mineralogist 88, 1825-1831. 
Mcdonough, W.F., Sun, S.S., 1995. The Composition of the Earth. Chem Geol 120, 223-253.

Medlin, C.C., Jowitt, S.M., Cas, R.A.F., Smithies, R.H., Kirkland, C.L., Maas, R.A., Raveggi, M., Howard, H.M., Wingate, M.T.D., 2015. Petrogenesis of the A-type, Mesoproterozoic Intra-caldera Rheomorphic Kathleen Ignimbrite and Comagmatic Rowland Suite Intrusions, West Musgrave Province, Central Australia: Products of Extreme Fractional Crystallization in a Failed Rift Setting. J Petrol 56, 493-525.

Melluso, L., Morra, V., Perrotta, A., Scarpati, C., Adabbo, M., 1995. The Eruption of the Breccia Museo (Campi-Flegrei, Italy) - Fractional Crystallization Processes in a Shallow, Zoned Magma Chamber and Implications for the Eruptive Dynamics. Journal of Volcanology and Geothermal Research 68, 325-339.

Mollo, S., Blundy, J.D., Iezzi, G., Scarlato, P., Langone, A., 2013. The partitioning of trace elements between clinopyroxene and trachybasaltic melt during rapid cooling and crystal growth. Contrib Mineral Petr 166, 1633-1654.

Mollo, S., Forni, F., Bachmann, O., Blundy, J.D., De Astis, G., Scarlato, P., 2016.

Trace element partitioning between clinopyroxene and trachy-phonolitic melts: A case study from the Campanian Ignimbrite (Campi Flegrei, Italy). Lithos 252253, 160-172.

Mollo, S., Masotta, M., 2014. Optimizing pre-eruptive temperature estimates in thermally and chemically zoned magma chambers. Chem Geol 368, 97-103.

Mollo, S., Masotta, M., Forni, F., Bachmann, O., De Astis, G., Moore, G., Scarlato, P., 2015. A K-feldspar-liquid hygrometer specific to alkaline differentiated magmas. Chem Geol 392, 1-8.

Orsi, G., Dantonio, M., Devita, S., Gallo, G., 1992. The Neapolitan Yellow Tuff, a Large-Magnitude Trachytic Phreatoplinian Eruption - Eruptive Dynamics, Magma Withdrawal and Caldera Collapse. Journal of Volcanology and Geothermal Research 53, 275-287.

Orsi, G., Petrazzuoli, S.M., Wohletz, K., 1999. Mechanical and thermo-fluid behaviour during unrest at the Campi Flegrei caldera (Italy). Journal of Volcanology and Geothermal Research 91, 453-470.

Pamukcu, A.S., Carley, T.L., Gualda, G.A.R., Miller, C.F., Ferguson, C.A., 2013. The Evolution of the Peach Spring Giant Magma Body: Evidence from Accessory Mineral Textures and Compositions, Bulk Pumice and Glass Geochemistry, and Rhyolite-MELTS Modeling. J Petrol 54, 1109-1148.

Pappalardo, L., Civetta, L., D'Antonio, M., Deino, A., Di Vito, M., Orsi, G., Carandente, A., de Vita, S., Isaia, R., Piochi, M., 1999. Chemical and Sr-isotopical evolution of the Phlegraean magmatic system before the Campanian Ignimbrite and the Neapolitan Yellow Tuff eruptions. Journal of Volcanology and Geothermal Research 91, 141-166.

Pappalardo, L., Ottolini, L., Mastrolorenzo, G., 2008. The Campanian Ignimbrite (southern Italy) geochemical zoning: insight on the generation of a supereruption from catastrophic differentiation and fast withdrawal. Contrib Mineral Petr 156, 1-26.

Pappalardo, L., Piochi, M., D'Antonio, M., Civetta, L., Petrini, R., 2002. Evidence for multi-stage magmatic evolution during the past 60 kyr at Campi Flegrei (Italy) deduced from $\mathrm{Sr}, \mathrm{Nd}$ and $\mathrm{Pb}$ isotope data. J Petrol 43, 1415-1434. 
Parmigiani, A., Faroughi, S., Huber, C., Bachmann, O., Su, Y., 2016. Bubble accumulation and its role in the evolution of magma reservoirs in the upper crust. Nature 532, 492-495.

Parmigiani, A., Huber, C., Bachmann, O., 2014. Mush microphysics and the reactivation of crystal-rich magma reservoirs. J Geophys Res-Sol Ea 119, 63086322.

Perrotta, A., Scarpati, C., 1994. The Dynamics of the Breccia-Museo Eruption (Campi-Flegrei, Italy) and the Significance of Spatter Clasts Associated with Lithic Breccias. Journal of Volcanology and Geothermal Research 59, 335-355. Pistone, M., Caricchi, L., Ulmer, P., Reusser, E., Ardia, P., 2013. Rheology of volatile-bearing crystal mushes: Mobilization vs. viscous death. Chem Geol 345, 16-39.

Polacci, M., Pioli, L., Rosi, M., 2003. The Plinian phase of the Campanian Ignimbrite eruption (Phlegrean Fields, Italy): evidence from density measurements and textural characterization of pumice. Bulletin of Volcanology 65, 418-432.

Putirka, K., 2008. Thermometers and barometers for volcanic systems. Reviews in Mineralogy \& Geochemistry 69, 61-120.

Rosi, M., Vezzoli, L., Aleotti, P., DeCensi, M., 1996. Interaction between caldera collapse and eruptive dynamics during the Campanian Ignimbrite eruption, Phlegraean Fields, Italy. Bulletin of Volcanology 57, 541-554.

Rowe, M.C., Ellis, B.S., Lindeberg, A., 2012. Quantifying crystallization and devitrification of rhyolites by means of X-ray diffraction and electron microprobe analysis. American Mineralogist 97, 1685-1699.

Sack, R.O., Carmichael, I.S.E., Rivers, M., Ghiorso, M.S., 1980. Ferric-Ferrous Equilibria in Natural Silicate Liquids at 1bar. Contrib Mineral Petr 75, 369-376. Scandone, P., Patacca, E., 1984. Tectonic evolution of the Central Mediterranean area. Gauthier-Villars, Paris, France.

Scarpati, C., Perrotta, A., 2012. Erosional characteristics and behavior of large pyroclastic density currents. Geology 40, 1035-1038.

Signorelli, S., Vaggelli, G., Francalanci, L., Rosi, M., 1999. Origin of magmas feeding the Plinian phase of the Campanian Ignimbrite eruption, Phlegrean Fields (Italy): constraints based on matrix-glass and glass-inclusion compositions. Journal of Volcanology and Geothermal Research 91, 199-220.

Sliwinski, J.T., Bachmann, O., Ellis, B.S., Dávila-Harris, P., Nelson, B.K., Dufek, J., 2015. Eruption of Shallow Crystal Cumulates during Explosive Phonolitic Eruptions on Tenerife, Canary Islands. J Petrol 56, 2173-2194.

Smith, R.L., Bailey, R.A., 1966. The Bandelier Tuff: A study of ash-flow eruption cycles from zoned Magma Chambers. Bull Volcanol 29, 83-103.

Sumner, J.M., Wolff, J., 2003. Petrogenesis of mixed-magma, high-grade, peralkaline ignimbrite 'TL' (Gran Canaria): diverse styles of mixing in a replenished, zoned magma chamber. Journal of Volcanology and Geothermal Research 126, 109-126.

Troll, V.R., Schmincke, H.-U., 2002. Magma Mixing and Crustal Recycling Recorded in Ternary Feldspar from Compositionally Zoned Peralkaline Ignimbrite 'A', Gran Canaria, Canary Islands. J Petrol 43, 243-270.

Wark, D.A., Hildreth, W., Spear, F.S., Cherniak, D.J., Watson, E.B., 2007. Preeruption recharge of the Bishop magma system. Geology 35, 235-238. 
Wolff, J.A., Ellis, B.S., Ramos, F.C., Starkel, W.A., Boroughs, S., Olin, P.H., Bachmann, 0., 2015. Remelting of cumulates as a process for producing chemical zoning in silicic tuffs: A comparison of cool, wet and hot, dry rhyolitic magma systems. Lithos 236-237, 275-286.

Wolff, J.A., Ramos, F.C., 2014. Processes in Caldera-Forming High-Silica Rhyolite Magma: $\mathrm{Rb}-\mathrm{Sr}$ and $\mathrm{Pb}$ Isotope Systematics of the Otowi Member of the Bandelier Tuff, Valles Caldera, New Mexico, USA. J Petrol 55, 345-375.

Wood, B.J., Blundy, J.D., 1997. A predictive model for rare earth element partitioning between clinopyroxene and anhydrous silicate melt. Contrib Mineral Petr 129, 166-181.

Worner, G., Schmincke, H.U., 1984. Mineralogical and Chemical Zonation of the Laacher See Tephra Sequence (East Eifel, West-Germany). J Petrol 25, 805-835. 


\section{Garigliano
river} $-41^{\circ} 20$

Rocca Monfina
Museo

Cl flow

$\mathrm{Cl}$ fallout $2 \begin{aligned} & \text { sampling } \\ & \text { localities }\end{aligned}$ sedimentary rocks of the Apennine 


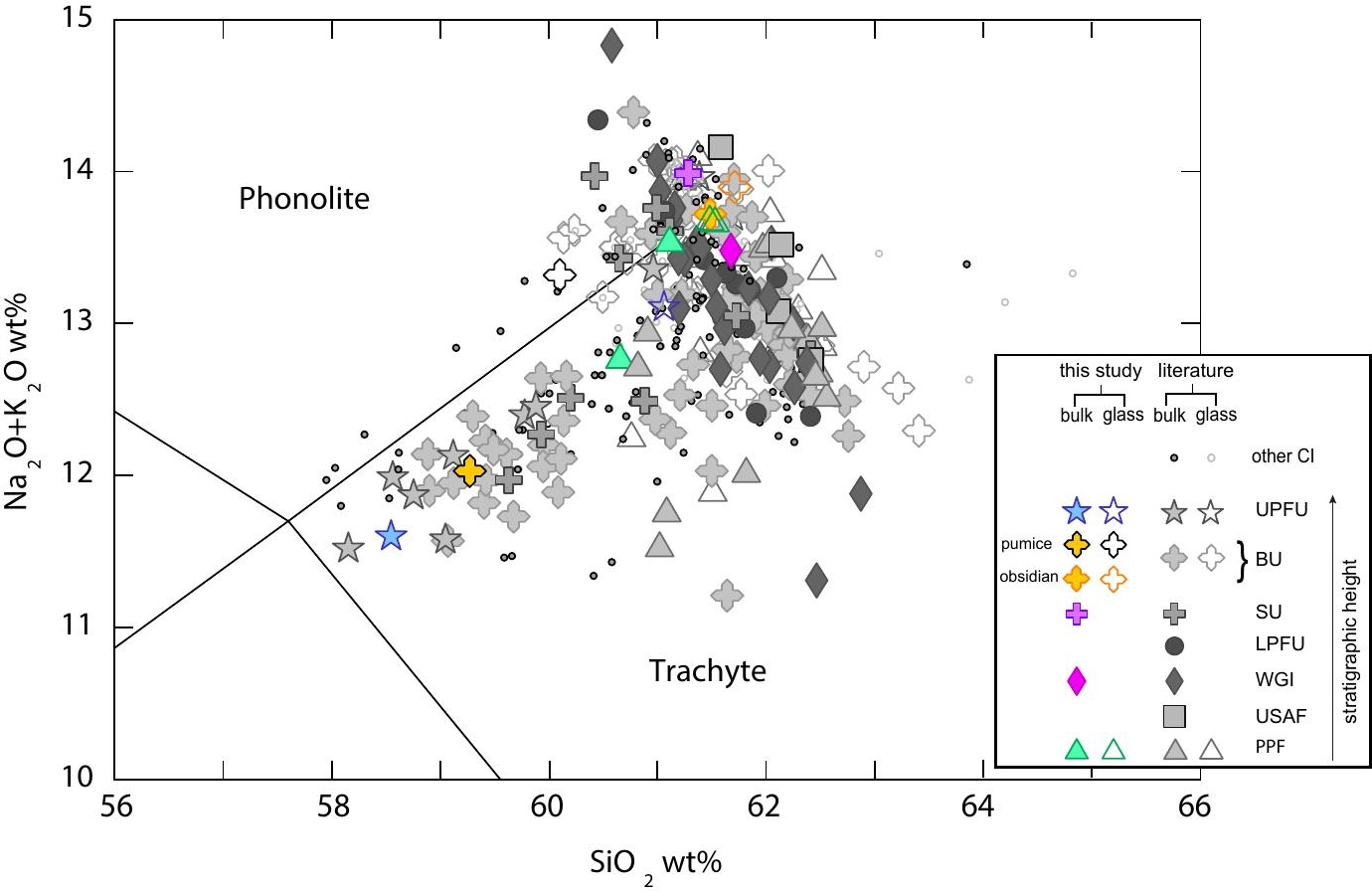




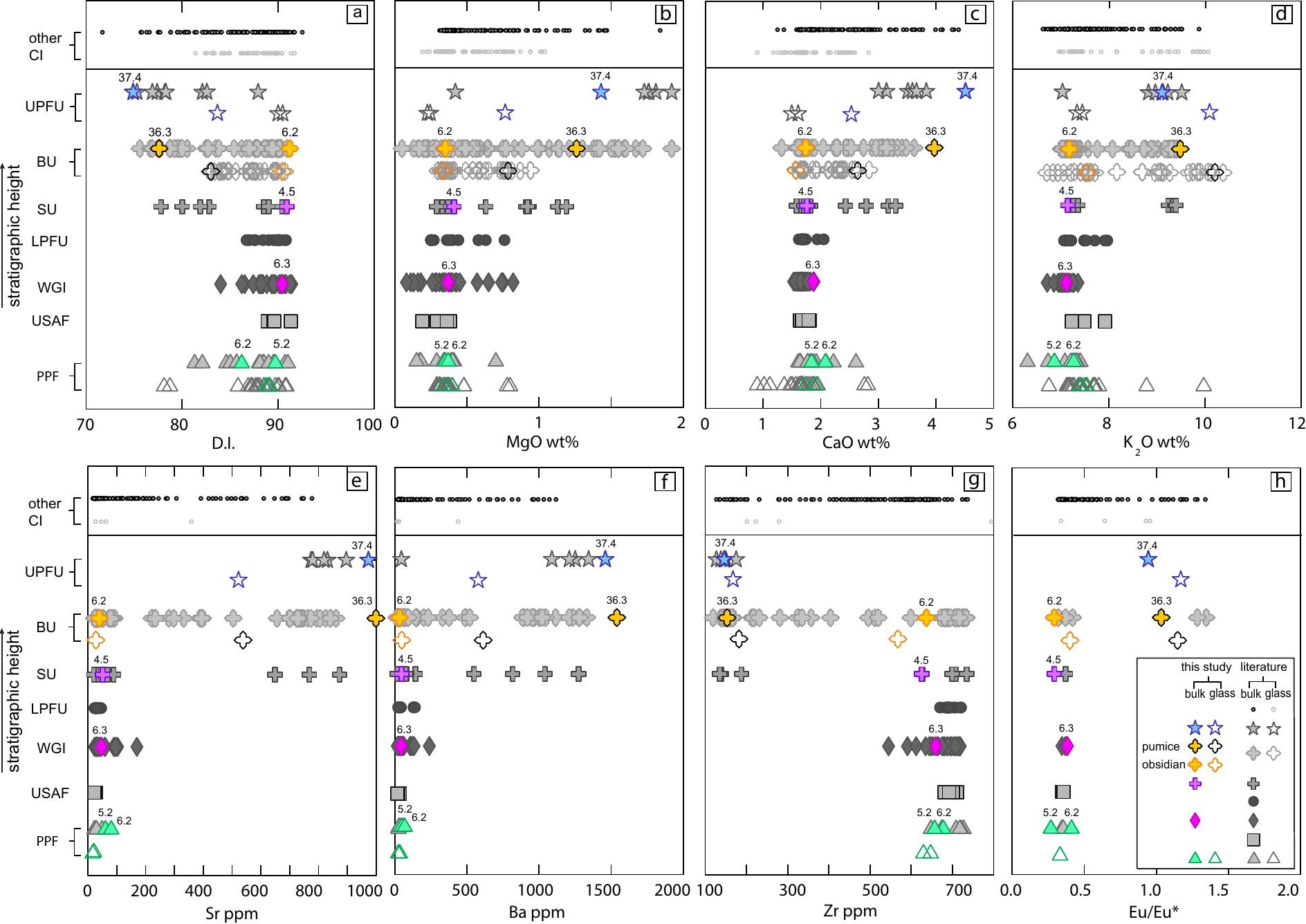




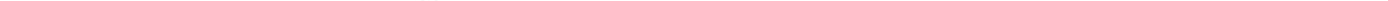



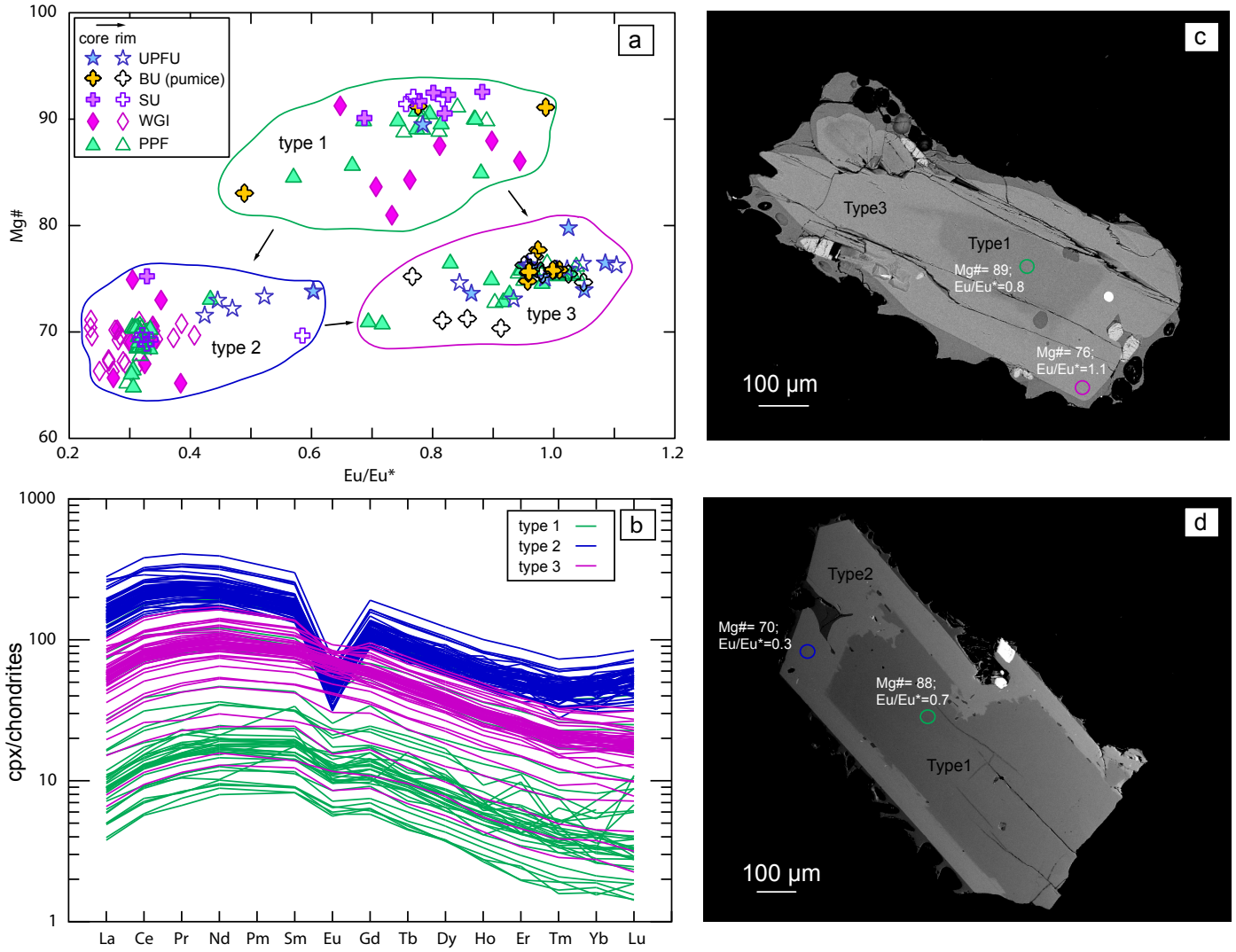


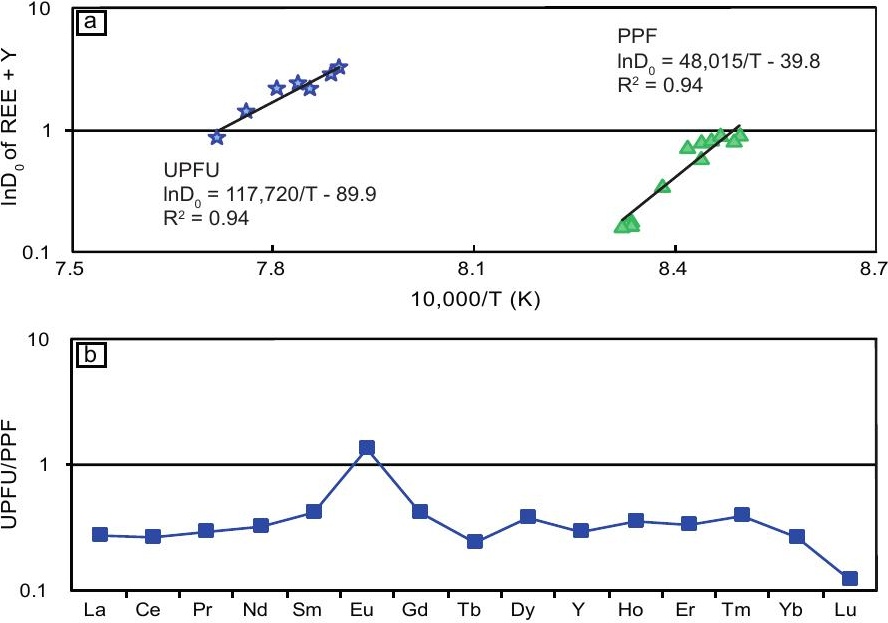




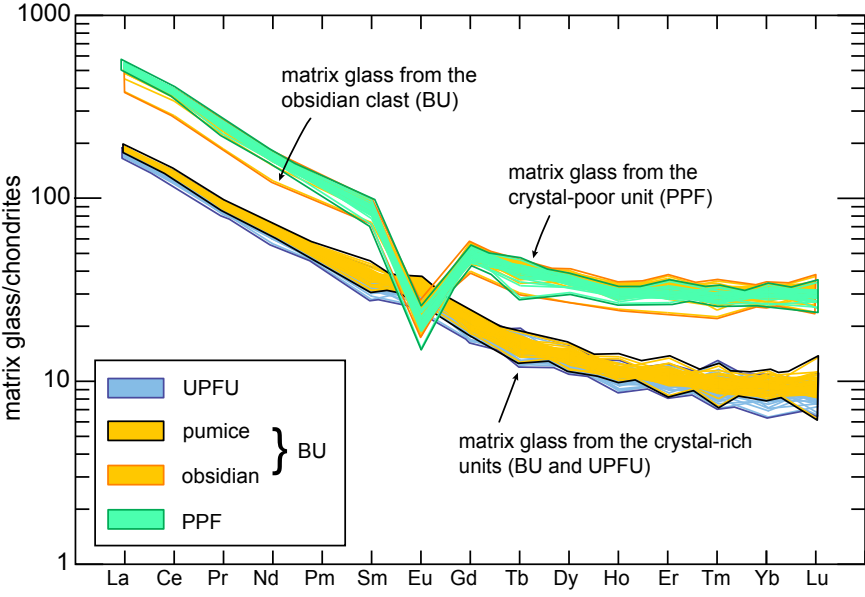


